\title{
POLYSACCHARIDE PRODUCTION IN BATCH PROCESS OF NEISSERIA MENINGITIDIS SEROGROUP C COMPARING FRANTZ, MODIFIED FRANTZ AND CATLIN 6 CULTIVATION MEDIA
}

\author{
Marcelo Fossa da Paz; Júlia Baruque-Ramos*; Haroldo Hiss; Márcio Alberto Vicentin; \\ Maria Betania Batista Leal; Isaías Raw \\ Instituto Butantan, Centro de Biotecnologia, São Paulo, SP, Brasil
}

Submitted: June 03, 2002; Returned to authors for corrections: August 22, 2002; Approved: February 20, 2003

\begin{abstract}
Polysaccharide of $N$. meningitidis serogroup $\mathrm{C}$ constitutes the antigen for the vaccine against meningitis. The goal of this work was to compare three cultivation media for production of this polysaccharide: Frantz, modified Frantz medium (with replacement of glucose by glycerol), and Catlin 6 (a synthetic medium with glucose). The comparative criteria were based on the final polysaccharide concentrations and the yield coefficient cell/polysaccharide $\left(\mathrm{Y}_{\mathrm{P} / \mathrm{X}}\right)$. The kinetic parameters: $\mathrm{pH}$, substrate consumption and cell growth were also determined. For this purpose, 9 cultivation runs were carried out in a $80 \mathrm{~L}$ New Brunswick bioreactor, under the following conditions: $42 \mathrm{~L}$ of culture medium, temperature $35^{\circ} \mathrm{C}$, air flow $5 \mathrm{~L} / \mathrm{min}$, agitation frequency $120 \mathrm{rpm}$ and vessel pressure $6 \mathrm{psi}$, without dissolved oxygen or $\mathrm{pH}$ controls. The cultivation runs were divided in three groups, with 3 repetitions each. The cultivation using the Frantz medium presented the best results: average of final polysaccharide concentration $=0.134 \mathrm{~g} / \mathrm{L}$ and $\mathrm{Y}_{\mathrm{P} / \mathrm{X}}=0.121$, followed by Catlin 6 medium, with results of $0.095 \mathrm{~g} / \mathrm{L}$ and 0.067 respectively. Considering the principal advantages in the use of the synthetic medium, i.e. facilitation of a cultivation and purification steps of the polysaccharide production process, there is a possibility that in the near future, Catlin 6 will replace the traditional Frantz medium.
\end{abstract}

Key words: Neisseria meningitidis, culture medium, vaccine, polysaccharide, batch cultivation

\section{INTRODUCTION}

Meningococcal disease is the major cause of death and morbidity throughout the world. Neisseria meningitidis is responsible for one third of all bacterial meningitis cases in the planet. The disease is serious and if not treated, mortality reaches $100 \%$ of cases (16).

In the late 1960s and early 1970s, Gotschlich et al. (11) developed an effective method for the purification of polysaccharides of $N$. meningitidis. They used the supernatant concentrates of bacterial cultures of serogroups A and C. Due to the anionic properties of these polysaccharides, the precipitation was performed by means of a cationic detergent (hexadecyltrimethyl ammonium bromide), followed by various organic solvent extractions and ultracentrifugation. The resulting compound was stable, suitable for purification and the final product induced a good immunological response in human beings. Basically, the same process is used nowadays for the serogroup C polysaccharide purification $(1,4,18)$.

Little information is available in literature about production of these polysaccharides in industrial scale $(1,4)$. The majority of the papers about this topic mention only the cultivation in little scale of this microorganism in solid or liquid Müller-Hinton medium in shaked flasks $(4,6,7)$.

Considering a larger scale, the cultivations in bioreactors are usually performed in Frantz medium $(1,2,3,4,8)$. On the other hand, Catlin 6, a based in original Catlin medium formulation (5), where glycerol was replaced by glucose as the carbon source,

\footnotetext{
* Corresponding author. Mailing address: Instituto Butantan (Centro de Biotecnologia). Av. Dr. Vital Brazil, 1500. 05503-900, São Paulo, SP, Brasil. Telephone: (+5511) 3726-7222 Ramal 2182. Fax: (+5511) 3726-1505. E-mail: jbaruque@butantan.gov.br
} 
was developed for the cultivation of $N$. meningitis serogroup B in bioreactor (10).

The original cultivation temperature for Neisseria meningitidis is between 36 and $37^{\circ} \mathrm{C}$ because it is a pathogenic microorganism. However, it was suggested that the cultivation at $35^{\circ} \mathrm{C}$ could increase the capsular polysaccharide yield due to a possible slower bacterial growth $(9,17)$.

In attempt to achieve high antigen (capsular polysaccharide) production under other stress conditions besides temperature, other authors cultivated $N$. meningitidis serogroup B in media with limiting concentrations of substrates and low $\mathrm{pH}$ (13). The cells developed under these conditions exhibited an extended "lag" phase, and after adaptation, their growth was relatively fast (about 2 to 3 hours to reach the maximum biomass concentration). Five to six hours after the growth end, the cells still contained appreciable amounts of polysaccharide (as sialic acid polymer) with a fraction associated to the bacterial reproduction and another no associated.

Based on this information, the experimental conditions of this study were directed towards change of carbon source in Frantz medium (glucose in normal medium and glycerol in the modified), to set of incubation temperature at $35^{\circ} \mathrm{C}$; and, based on the hypothesis that stress could increase the polysaccharide production, lack of control of the $\mathrm{pH}$ and dissolved oxygen in the medium.

A study of polysaccharide production in batch cultivation of $N$. meningitidis serogroups $\mathrm{C}$, using the same process conditions and different culture media, is useful to obtain the relationship between carbon source substrate and polysaccharide formation. In order to facilitate the purification, a process that provides high polysaccharide formation with the lowest relationship between this product and cellular nitrogen amount needs to be developed. In this study, $N$. meningitidis serogroup $\mathrm{C}$ was batch cultivated in Frantz medium (8), traditionally used for bioreactor cultivation of this microorganism, in modified Frantz medium $(8,9)$ and in Catlin 6 medium (5). The following factors were used as comparison parameters: maximum biomass concentration $\left(\mathrm{X}_{\max }\right)$, final polysaccharide concentration $\left(\mathrm{P}_{\mathrm{f}}\right)$ and cell/polysaccharide yield factor $\left(\mathrm{Y}_{\mathrm{P} / \mathrm{X}}\right)$.

\section{MATERIALS AND METHODS}

\section{Cultivation of the microorganism}

The inoculum was prepared according to Gotschlich et al. (11). The contents of two ampoules, containing the meningococcal strain IMC 2135 (supplied by Instituto Adolfo Lutz, SP, Brazil), maintained in $0.5 \mathrm{~mL}$ of Greaves medium $(12)$ at $-70^{\circ} \mathrm{C}$, having a mean value of $6.0 \times 106 \mathrm{CFU} / \mathrm{mL}$, were streaked out onto four Müller-Hinton agar slant tubes (14). The tubes were incubated at $35^{\circ} \mathrm{C}$ during $12 \mathrm{~h}$ in a candle jar $(5-10 \% \mathrm{CO} 2)$. The microorganisms from each slant tube were ressuspended in the elected culture medium (Table 1) and transferred to $250 \mathrm{~mL}$ conical flasks, containing $50 \mathrm{~mL}$ of this medium. The flasks were incubated at $35^{\circ} \mathrm{C}$ for $5 \mathrm{~h}$ in a rotary shaker at $120 \mathrm{rpm}$. This culture was transferred to a $2 \mathrm{~L}$ conical flask, containing $400 \mathrm{~mL}$ of the same medium, and cultivated under the conditions previously described. Possible contaminations of cultures were monitored by Gram staining. The contents of two of these conical flasks were used as inoculum for the bioreactor (New Brunswick model MPP 80 - total capacity $80 \mathrm{~L}$ ) with $40 \mathrm{~L}$ of elected culture medium (Table 1). The media for the inoculum and for the bioreactor were sterilized by filtration through a $0.2 \mu \mathrm{m}$ Millipore filter.

The cultivation conditions were: temperature $35.0^{\circ} \mathrm{C}$; air flow rate $5 \mathrm{~L} / \mathrm{min}(0.125 \mathrm{vvm}$, superficial aeration); agitation frequency $120 \mathrm{rpm}$ (with 2 Rushton six blade disc turbines); vessel head space pressure $6 \mathrm{psi}$; height and diameter of the vessel 72 and $40 \mathrm{~cm}$, respectively; turbine diameter $16.5 \mathrm{~cm}$, one located at 10 $\mathrm{cm}$ from the vessel bottom and the other at $35 \mathrm{~cm}$. Four baffles were installed, in order to enhance the mixture efficiency. The oxygen volumetric transfer coefficient $\left(\mathrm{k}_{\mathrm{L}} \mathrm{a}\right)$ was near $0.07 \mathrm{~min}^{-1}$ before the inoculation $(\mathrm{t}=0 \mathrm{~h})$.

The culture media composition is indicated in Table 1.

The batch cultivation runs, all under the same operation conditions, were divided into three groups, each one with three repetitions: the first one with original Frantz medium, the second employing the modified Frantz medium; and the last, with Catlin 6 medium.

\section{Analytical methods}

Cell Concentration: Expressed as dry biomass, determinated by a centrifugation of a sample at $10,000 \mathrm{~g}$, followed by the pellet drying at $60^{\circ} \mathrm{C}$ during $48 \mathrm{~h}$;

Table 1. Cultivation Media Composition (g/L).

\begin{tabular}{cccc}
\hline Compounds & Frantz & Modified Frantz & Catlin 6 \\
\hline L-Glutamic Acid & 1.60 & 1.60 & 3.90 \\
L-Cysteine.HCl & 0.02 & 0.02 & 0.10 \\
L-Arginine.HCl & - & - & 0.15 \\
L-Serine & - & - & 0.50 \\
Glycine & - & - & 0.25 \\
$\mathrm{CaCl}_{2} .2 \mathrm{H}_{2} \mathrm{O}$ & - & - & 0.03 \\
$\mathrm{NaCl}$ & 6.00 & 6.00 & 5.80 \\
$\mathrm{Na}_{2} \mathrm{HPO}_{4} .12 \mathrm{H}_{2} \mathrm{O}$ & 6.24 & 6.24 & - \\
$\mathrm{K}_{2} \mathrm{HPO}_{4}$ & - & - & 4.00 \\
$\mathrm{~K}_{2} \mathrm{SO}_{4}$ & - & - & 1.00 \\
$\mathrm{KCl}$ & 0.09 & 0.09 & - \\
$\mathrm{NH}_{4} \mathrm{Cl}$ & 1.25 & 1.25 & 1.00 \\
$\mathrm{MgCl}_{2} .6 \mathrm{H}_{2} \mathrm{O}$ & - & - & 0.40 \\
$\mathrm{MgSO}_{4} .7 \mathrm{H}_{2} \mathrm{O}$ & 1.23 & 1.23 & - \\
$\mathrm{Glucose}$ & 5.00 & - & 10.00 \\
$\mathrm{Glycerol}$ & - & 5.00 & - \\
$\mathrm{Fe}(\mathrm{III}) . \mathrm{Citrate}$ & - & - & 0.04 \\
Yeast Extract & 2.00 & 2.00 & - \\
\hline
\end{tabular}


Glucose Concentration: Glucoseoxidase method (colorimetric) (19);

Glycerol Concentration: The method used (15) was based on the glycerol oxidation by sodium periodate, in which glycerol reacts with sodium periodate in acid solution generating aldehyde and formic acid. Formic acid was titrated with a $\mathrm{NaOH}$ solution $(0.125 \mathrm{~N})$, and the spent volume corresponded to glycerol concentration;

Polysaccharide Concentration: Cells were disrupted and precipitated by the addition of Cetavlon (Merck Laboratories) to the sample (11). After centrifugation, the supernatant was eliminated and the precipitated biomass ressuspended in a $1 \mathrm{M}$ $\mathrm{CaCl}_{2} \cdot 2 \mathrm{H}_{2} \mathrm{O}$ solution. The suspension was centrifuged again and the supernatant collected for the polysaccharide determination using the Resorcinol- $\mathrm{HCl}$ colorimetric method $(11,20)$, which detects the polysaccharide monomers (sialic acids) formed after acid hydrolysis;

pH: Measured by an on-line sterilizable electrode (Ingold model 465-90);

Yield coefficient: Calculations were performed by means of the ratio between polysaccharide production and cell biomass generated $\left(\mathrm{Y}_{\mathrm{P} / \mathrm{X}}\right)$ at a given cultivation time.

\section{RESULTS AND DISCUSSION}

Before any other considerations, it can be seen from Figs. 1 and 3, that there was the production of growth associated polysaccharide in the bacterial population up to the $12^{\text {th }}$ hour of cultivation. After this period, up to the end of the cultivation in the stationary phase - where there was no bacterial population growth, polysaccharide production continued, in other words, there was non-growth associated production. The detailed analysis of this phenomenon has been described in an earlier article (2). As far as the other topic related to the current article is concerned, dealing with the analysis of nitrogen consumption and its cellular assimilation in the growth kinetics of $N$. meningitidis serogroup $\mathrm{C}$, this has also been described in detail in another reference (3).

\section{Comparison of the consumption of different sources of carbon}

The graphs, showing the kinetic behavior of each group of experiments (defined in Table 2) are shown in Figs. 1 to 4.

In the case of the kinetic consumption of glucose in experiments 1 to 3 where the Frantz medium was used (Table 2 and Fig. 2), a residual value greater than $1 \mathrm{~g} / \mathrm{L}$ was observed at the end of the cultivation, while in those where the Catlin 6 medium was used, experiments 7 to 9 (Table 2), the residual value of the substrate was between 3 and $5 \mathrm{~g} / \mathrm{L}$. These results indicate that the concentration of this component can be adjusted in the formulation of these cultures so as to avoid

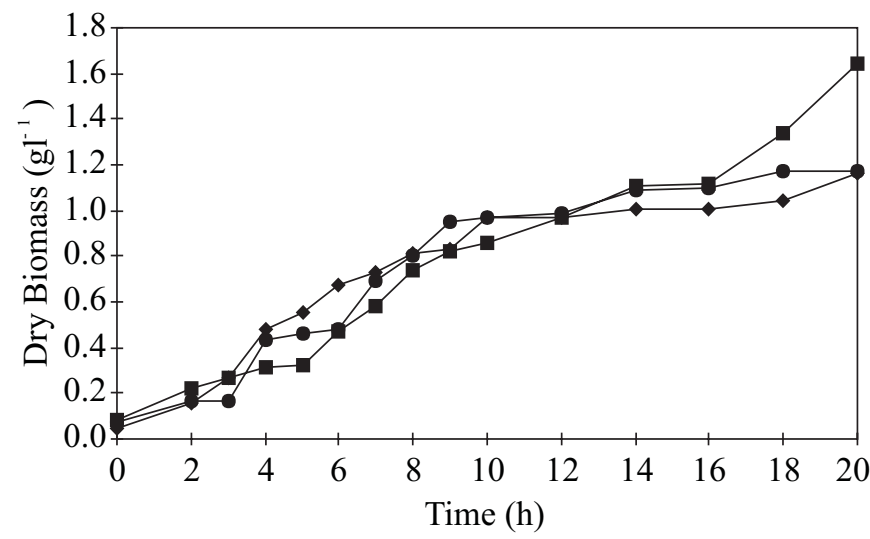

Figure 1. Dry biomass concentration; Frantz medium $(\diamond)$, modified Frantz medium ( $(\mathbf{)}$ and Catlin 6 medium ( $\square$ ).

Table 2. Values of final biomass concentrations $\left(\mathrm{X}_{\max }\right)$, final polysaccharide concentrations $\left(\mathrm{P}_{\mathrm{f}}\right)$ and cell/polysaccharide yield factors $\left(\mathrm{Y}_{\mathrm{P} / \mathrm{X}}\right)$ for the experiments 1 to 9.

\begin{tabular}{ccccccccc}
\hline \multirow{2}{*}{ Batch Assay Medium } & $\begin{array}{c}\text { Assay } \\
\text { Number }\end{array}$ & $\begin{array}{c}\text { Culture } \\
\text { Duration }(\mathrm{h})\end{array}$ & $\begin{array}{c}\mathrm{X}_{\max } \\
(\mathrm{g} / \mathrm{L})\end{array}$ & $\begin{array}{c}\text { Average } \mathrm{X}_{\max } \\
(\mathrm{g} / \mathrm{L})\end{array}$ & $\begin{array}{c}\mathrm{P}_{\mathrm{f}} \\
(\mathrm{g} / \mathrm{L})\end{array}$ & $\begin{array}{c}\text { Average } \mathrm{P}_{\mathrm{f}} \\
(\mathrm{g} / \mathrm{L})\end{array}$ & $\begin{array}{c}\mathrm{Y}_{\mathrm{P} / \mathrm{X}} \\
\text { Average } \\
\mathrm{Y}_{\mathrm{P} / \mathrm{X}}\end{array}$ \\
\hline \multirow{3}{*}{ Frantz } & 1 & 20 & 1.16 & & 0.141 & & 0.122 & \\
& 2 & 20 & 1.09 & 1.11 & 0.128 & 0.134 & 0.117 & 0.121 \\
& 3 & 20 & 1.07 & & 0.133 & & 0.124 & \\
\hline \multirow{3}{*}{ Modified Frantz } & 4 & 20 & 1.17 & & 0.032 & & 0.027 & \\
& 5 & 20 & 0.84 & 1.08 & 0.027 & 0.030 & 0.032 & 0.028 \\
& 6 & 20 & 1.24 & & 0.030 & & 0.024 & \\
\hline \multirow{2}{*}{ Catlin 6 } & 7 & 20 & 1.64 & & 0.105 & & 0.064 & \\
& 8 & 20 & 1.52 & 1.44 & 0.100 & 0.095 & 0.066 & 0.067 \\
\hline
\end{tabular}




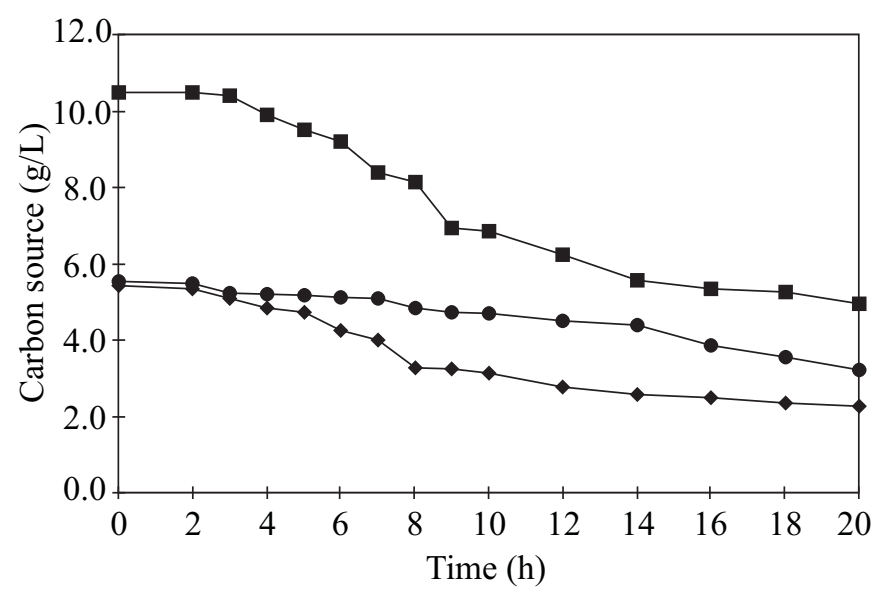

Figure 2. Carbon source concentration; Frantz medium $(\diamond)$, modified Frantz medium ( $)$ and Catlin 6 medium ( $\square$ ).

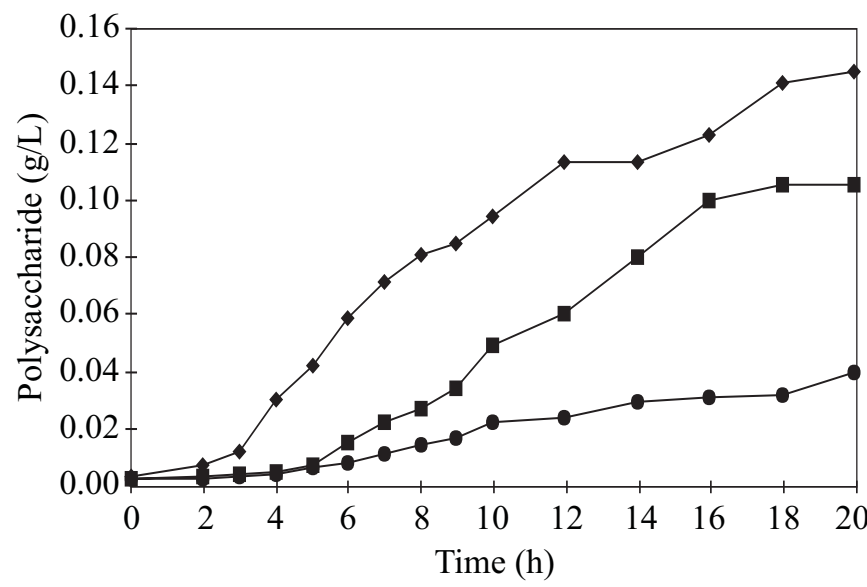

Figure 3. Polysaccharide concentration; Frantz medium $(\diamond)$, modified Frantz medium (O) and Catlin 6 medium ( $\square$ ).

excess of glucose at the end of the cultivation. Furthermore, by analyzing the glucose consumption kinetics and (Figs. 2 and 4), it was observed that in all the experiments using glucose, the $\mathrm{pH}$ fell, during the cultivation, to values of around 5.0 (Fig. 4), indicating that in these cultivations the consumption of glucose yielded acid metabolites.

In experiments 4 to 6 , which were carried out using the modified Frantz medium, where glycerol was used as a source of carbon, there was also a residue of this substrate at the end of the cultivations (Fig. 2). Furthermore, as far as the consumption kinetics and $\mathrm{pH}$ are concerned (Figs. 2 and 4), there was a slight rise in the $\mathrm{pH}$ values as the cultivation progressed. This behavior was contrary to that observed in the other groups of experiments. In the experiments carried out using the modified Frantz medium,

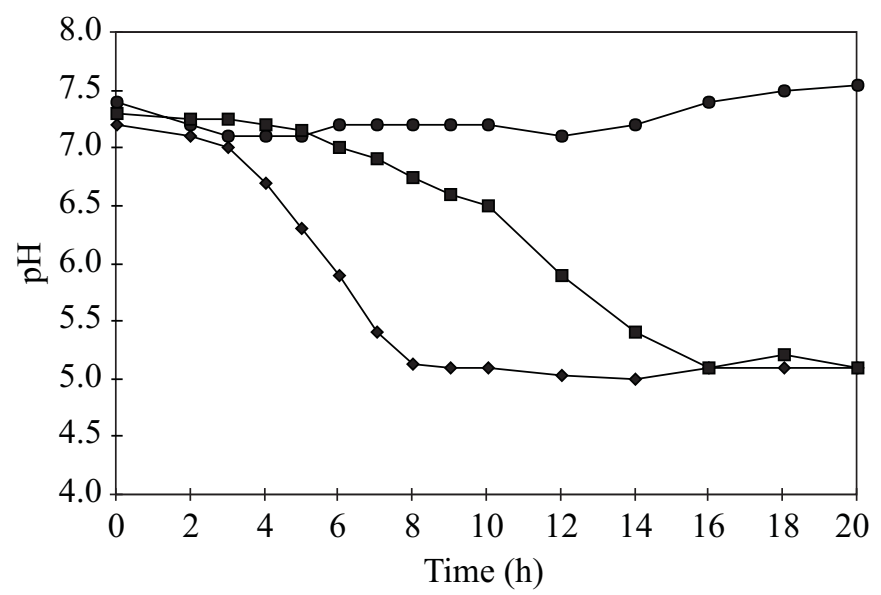

Figure 4. pH; Frantz medium $(\diamond)$, modified Frantz medium $(\mathbf{O})$ and Catlin 6 medium ( $\square)$.

the $\mathrm{pH}$ values increased with time, with two points of inflection after the $5^{\text {th }}$ and $13^{\text {th }}$ hours of the cultivation, reaching values around 7.7 at the end of the cultivation. This fact indicates that, not only were acid metabolites not formed, but also that sequential consumption of amino acids as a source of carbon may have taken place together with the consumption of glycerol (Fig. 2).

\section{Comparison of polysaccharide production for the three cultivation media}

The relationship between biomass and polysaccharide production is extremely important in large-scale production. Since, in order to lower the costs of capsular polysaccharide production (through the cultivation of $N$. meningitidis serogroup $\mathrm{C}$ in a bioreactor) and the purification process of the capsular polysaccharide obtained, it is essential to pay attention to two criteria: attaining the maximum polysaccharide concentration at the end of the cultivation in the bioreactor $\left(\mathrm{P}_{\mathrm{f}}\right)$ and simultaneously attaining the maximum cell / polysaccharide yield factor $\left(\mathrm{Y}_{\mathrm{P} / \mathrm{X}}\right)$, bearing in mind that, in the purification process, the rest of the cell structure is a contaminant.

Comparing the results obtained with other data described in the literature for industrial scale production, excluding the articles by Aymé et al. (1) (which refers to the production of $N$. meningitidis serogroup A polysaccharide) and by Fu et al. (10) (which refers to the production of $N$. meningitidis serogroup B polysaccharide), there remained only the study by Carty et al. (4), since this was the only study found, prior to those by the authors of this paper, which was concerned with the industrial production of $N$. meningitidis polysaccharides of the same group, that is serogroup $\mathrm{C}$.

Carty et al. (4) obtained a final polysaccharide concentration value of $0.16 \mathrm{~g} / \mathrm{L}$ after a cultivation period of 22 hours. This value is compatible with the results obtained in the current 
study (Table 2). Furthermore, these authors concluded that by operating with constant aeration and agitation rates, they could obtain an increase in polysaccharide production. Because of this, they suggested that polysaccharide production is related to cellular growth, which is constrained by the limited availability of oxygen, just as it was in this study.

A Student " $t$ " test at the 5\% significance level was carried out to compare the data obtained in this study from the groups of experiments specified in Table 2. The statistical conclusion, confirming visual analysis of the results, was that greater final concentrations of polysaccharide $\left(\mathrm{P}_{\mathrm{f}}\right)$ and greater cell / polysaccharide yield factors $\left(\mathrm{Y}_{\mathrm{P} / \mathrm{X}}\right)$ were obtained in the group of experiments 1 to 3 where the Frantz medium was used (an average of $0.134 \mathrm{~g} / \mathrm{L}$ and 0.121 respectively).

The same analysis showed that the worst results (an average of $0.030 \mathrm{~g} / \mathrm{L}$ and 0.028 respectively) were obtained in the group of experiments 4 to 6 where the modified Frantz medium was used. In addition, statistical tests on the biomass values obtained at the end of the cultivations $\left(\mathrm{X}_{\max }\right)$ were also carried out. They showed that these biomass values must be considered similar for all the nine experiments. These conclusions show that the use of the modified Frantz medium is only of interest when the production of a large biomass of $N$. meningitidis together with low or no polysaccharide production is required. For the aims of this study, this medium must be discarded.

The results obtained in the group of experiments 7 to 9 , where the Catlin 6 medium was used (an average of $0.095 \mathrm{~g} / \mathrm{L}$ and 0.067 respectively) show that this medium can be considered an interesting possibility for $N$. meningitidis polysaccharide production, since not only does in give reasonable final yield values, it is a synthetic medium, that is, it is chemically defined, whereas the other two media used in this study are chemically undefined. In spite of the experiments carried out using the Catlin 6 medium not having given the best values for the yield factor $\left(\mathrm{Y}_{\mathrm{P} / \mathrm{X}}\right)$, compared to those carried out using the Frantz medium, which implies that there is a higher concentration of cellular contaminants present during the polysaccharide purification process, it must be borne in mind that the other two chemicallyundefined cultivation media, also contain undesirable contaminants right up to the end of the cultivation process, something which does not happen using the Catlin 6 medium.

Another advantage of the Catlin 6 medium, when compared to the other two cultivation media which use dialyzed yeast extract (Table 1), concerns the fact that it is not necessary to dialyze any of its components, resulting in an additional operational saving. In addition to the above, considering that the final product - a vaccine against the diseases caused by $N$. meningitidis serogroup $\mathrm{C}$-is an immunobiological injection, the use of the Catlin 6 medium satisfies the cGMP (current good manufacturing practice) and the FDA (Food and Drug Administration) specifications. These norms specify this type of product to be manufactured by synthetic media whenever possible (10).
The results obtained from the experiments that used the Catlin 6 medium (Table 2), where the initial glucose concentration was $10.0 \mathrm{~g} / \mathrm{L}$ (Table 1) and the residual glucose value at the end of the cultivation was between 3 and $5 \mathrm{~g} / \mathrm{L}$ (Fig. 2), suggest that the greater glucose excess in the Catlin 6 medium compared to the Frantz medium may be related to the lower final polysaccharide concentration values $\left(\mathrm{P}_{\mathrm{f}}\right)$ and yield factors $\left(\mathrm{Y}_{\mathrm{P} / \mathrm{X}}\right)$ obtained when the Catlin 6 medium is used compared to those obtained when the Frantz medium is used, where the initial glucose concentration was $5 \mathrm{~g} / \mathrm{L}$ (Table 1) and the residual values at the end of the process were close to $1 \mathrm{~g} / \mathrm{L}$ (Fig. 2). Maybe, an alteration of the Catlin 6 medium composition, where the initial glucose concentration is lowered, could improve the results obtained.

By also taking into account the conclusions of an earlier study, referring to the kinetics of nitrogen consumption by $N$. meningitidis (3), another way of optimizing polysaccharide production using the Catlin 6 medium, may be by the limitation of an essential nutrient in the medium defined such as, for example, the source of nitrogen in the presence of excess glucose. Under these conditions, a greater production of polysaccharide may take place. Therefore, in another study is already underway to determine the influence of glucose concentration on the $N$. meningitidis serogroup $\mathrm{C}$ polysaccharide production medium and, following this, another study will be carried out to determine the effect of limiting nitrogen, with an excess of glucose, on the generation of this product.

Thus, in view of the advantages of the synthetic medium, which are lower costs and easier cultivation and purification stages in the polysaccharide production process, there is the possibility of, once its formation has been adapted, the Catlin 6 medium substituting the traditional Frantz medium.

\section{ACKNOWLEDGEMENTS}

Fundação Butantan, FUNDAP, CAPES and FAPESP supported this work. We thank Mr. Máximo de Moraes, Mr. Lourivaldo Inácio de Souza and Mrs. Inês do Amaral Maurelli for their technical assistance and Mrs. Salete Vargas for the material purchase.

\section{RESUMO}

\section{Produção de polissacarídeo em processo de cultivo descontínuo de Neisseria meningitidis sorogrupo C comparando os meios de cultivo Frantz, Frantz modificado e Catlin 6.}

O polissacarídeo de $N$. meningitidis sorogrupo C constitui o antígeno para a elaboração da vacina contra a meningite C. O objetivo deste trabalho foi comparar três meios de cultivo para produção desse polissacarídeo: Frantz, Frantz modificado (com a 
substituição de glicose por glicerol) e Catlin 6 (meio sintético com glicose). Os critérios comparativos foram baseados nas concentrações finais de polissacarídeo e o fator de conversão célula/polissacarídeo $\left(\mathrm{Y}_{\mathrm{P} / \mathrm{X}}\right)$. Também foram determinados os parâmetros cinéticos de $\mathrm{pH}$, consumo de substrato e crescimento celular. Para essa finalidade, foram efetuados nove cultivos em um biorreator New Brunswick de $80 \mathrm{~L}$, sob as seguintes condições: $42 \mathrm{~L}$ de meio de cultura, temperatura de $35^{\circ} \mathrm{C}$, vazão de ar de $5 \mathrm{~L} /$ min, freqüência de agitação de 120 rpm e pressão da dorna de 6 psi, sem controles de oxigênio dissolvido ou $\mathrm{pH}$. Os cultivos foram divididos em 3 grupos, com 3 repetições cada um. O cultivo usando o meio de Frantz apresentou os melhores resultados: medias de concentração final de polissacarídeo de $0,134 \mathrm{~g} / \mathrm{L}$ e $\mathrm{Y}_{\mathrm{P} /}$ $\mathrm{x}=0,121$, seguidos pelo meio de Catlin 6 , com resultados de 0,095 $\mathrm{g} / \mathrm{L}$ e 0,067 respectivamente. Considerando as principais vantagens do uso do meio sintético, como por exemplo, facilitação do cultivo e etapas de purificação do processo de produção do polissacarídeo, há a possibilidade do meio de Catlin 6 substituir o tradicional meio de Frantz em futuro próximo.

Palavras-chave: Neisseria meningitidis, meio de cultura, vacina, polissacarídeo, cultivo descontínuo.

\section{REFERENCES}

1. Aymé, G.; Donikian, R.; Mynard, M.C.; Lagrandeur,G. Production and Controls of Serogroup A Neisseria meningitidis Polysaccharide Vaccine. In: Table Ronde Sur L'Immunoprophilaxie de la Meningite Cerebro-Spinale. Edition Fondation Mérieux, Lyon (France), 1973, p. 4-30.

2. Baruque-Ramos, J.; Hiss, H.; Paz, M.F. et al. Batch cultivation kinetics of Neisseria meningitidis (serogroup C) in Frantz medium I. Growth and polysaccharide production. Arch. Biol. Technol. 39(1): 215$220,1996$.

3. Baruque-Ramos, J.; Hiss, H.; Paz, M.F. et al. Nitrogen consumption during batch cultivation of Neisseria meningitidis (serogroup C) in Frantz medium. Bras. Rev. Microb., 32(4): 305-310, 2001.
4. Carty, C.E. et al. Cultivation studies of Neisseria meningitidis serogroups A, C, W135 and Y. Developments in Industrial Microbiology (edited by Merck Laboratories), 25: 695-700, 1984.

5. Catlin, B.W. Nutritional profiles of Neisseria lactamica, gonorrhoeae and meningitidis, in chemicaly defined media. J. Inf. Dis., 128(2): 178-194, 1973

6. De Voe, I.W.; Gilchrist, J.E. Release of Endotoxin in the Form of Cell Wall Blebs During Vitro Growth of Neisseria meningitidis. J. Exp. Med., 138: 1156-1167, 1973.

7. Difco Laboratories. Difco manual $10^{\text {th }}$ edn. Detroit, USA, 1984. p. 582-584.

8. Frantz, I.D. Jr. Growth Requirements of the Meningococcus. J. Bact., 43: 757-761, 1942.

9. Frasch, C.E. Personal information in visitation to the Instituto Butantan in march, 1991.

10. Fu, J. et al. Recent advances in the large scale cultivation of Neisseria meningitidis Group B for the production of an outer membrane protein complex. Bio/Technol., 13: 170-174, 1995.

11. Gotschlich, E.C.; Liu, T.Y.; Artenstein, M.D. Human immunity to the meningococcus - III. preparation and immunochemical properties of the group A, group B, and group C menningococcal polysaccharides. J. Exp. Med., 129(2): 1349-1365, 1969.

12. Greaves, R.I.N. Preservation of living cells by freezedrying. Ann. N.Y. Acad. Sci., 85: 723, 1960.

13. Mason, L.; Holbein, B.E. Influence of nutrient limitation and low $\mathrm{pH}$ on serogroup B Neisseria meningitidis capsular polysaccharide levels: correlation with virulence for mice. Infect. Immun. 47(2): 465-471, 1985.

14. Müller, H.; Hinton, J.A. A proetin-free medium for primary isolation of the gonococcus and meningococcus. Proc. Soc. Exp. Biol. Med., 48: $330,1941$.

15. Official methods and recommended practices of the American Oil Chemistry Society (AOCS). Illinois, USA, 1987. Section E, method Ea-6-51.

16. Plotkin, S.A.S.; Mortimer, E.A. Jr. Meningoccocal vaccines. In: Vaccines. Philadelphia: W.B. Saunders Company, 1988, p. 263-270.

17. Poolman, J.T. Development of a meningococcal Vaccine. Infect. Agents Dis., 4: 13-28, 1995.

18. Protocol of production of group $\mathrm{C}$ meningococcal polysaccharide. Washington, D.C., Walter Reed Army Institute of Research, Walter Reed Medical Center, 1970.

19. Spiro R.G. Analysis of sugar found in glycoproteins. In: Methods in enzymology. Vol. 8. New York: Academic Press, 1966, p. 3-13.

20. Svennerholm, L. Quantitative estimation of sialic acids. II. A colorimetric resorcinol-hydrochloric acid method. Bioch. Bioph., 24: 604-611, 1957. 